\title{
PENGARUH LOCUS OF CONTROL INTERNAL DAN INSENTIF TERHADAP PERILAKU MENDAUR ULANG
}

\author{
Oleh \\ Rina Sari Qurniawati \\ Dosen Tetap STIE AMA Salatiga
}

\begin{abstract}
Abstrak
Pertambahan penduduk di dunia ini diikuti pula oleh bertambahnya jumlah sampah yang dihasilkan oleh rumah tangga. Sampah ini akan mengakibatkan adanya kerusakan lingkungan jika tidak dikelola dengan baik. Kesadaran masyarakat akan adanya bencana alam yang diakibatkan karena sampah tidak diikuti dengan perilaku mereka untuk mendaur ulang sampah yang mereka hasilkan. Kolektivisme dan locus of control internal sebagai orientasi nilai dasar manusia yang berhubungan dengan interaksi seseorang dengan lingkungan sekitarnya mempengaruhi perilaku mendaur ulang. Nilai dasar ini akan berpengaruh pada konstruk psikologi yang lebih spesifik yaitu keyakinan tentang daur ulang. Insentif juga penting dalam menjelaskan perilaku mendaur ulang.

Penelitian ini bertujuan untuk menguji pengaruh locus of control internal pada keyakinan dan insentif pada perilaku mendaur ulang. Hipotesis yang dikembangkan diuji menggunakan data yang diperoleh melalui survey pada 100 anggota suatu rumah tangga di Salatiga. Penelitian ini didasarkan pada studi confirmatory model. Program statistik SPSS digunakan untuk menguji validitas dan reliabilitas instrument dan hipotesis penelitian. Temuan dari hasil regresi telah membuktikan semua hubungan yang dihipotesiskan. Locus of control internal terbukti berpengaruh pada perilaku daur ulang. Begitu juga dengan variabel insentif yang terbukti berpengaruh pada perilaku daur ulang.
\end{abstract}

\section{Kata Kunci: Locus of Control Internal, Perilaku Mendaur Ulang, Insentif}

\section{PENDAHULUAN}

Kesadaran masyarakat pada lingkungan akibat adanya ancaman terjadinya bencana yang disebabkan kerusakan lingkungan terus meningkat sejak dicanangkannya "Hari Bumi” (Earth Day) 30 tahun yang lalu (Kim dan Choi, 2005). Bencana ini di masa yang akan datang dapat mengancam kehidupan generasi saat ini sampai keturunan mereka. Salah satu penyebab kerusakan lingkungan adalah sampah. Pertambahan jumlah 
penduduk di dunia ini tentu akan berdampak pula terhadap peningkatan jumlah sampah yang dihasilkan. Peningkatan jumlah sampah yang tidak diikuti oleh perbaikan dan peningkatan sarana dan prasarana pengelolaan sampah mengakibatkan permasalahan sampah menjadi komplek, antara lain sampah tidak terangkut dan terjadi pembuangan sampah liar, sehingga dapat menimbulkan berbagai penyakit, kota yang kotor, bau tidak sedap, mengurangi daya tampung sungai dan lain-lain.

Kaplan (2000) menyatakan bahwa banyak orang peduli dan prihatin terhadap isu-isu lingkungan, tapi hal ini tidak selalu tercermin pada perilaku mereka. Perilaku masyarakat Indonesia untuk mendaur ulang belum menunjukkan kearah yang positif. Jangankan mendaur ulang, masyarakat sampai saat ini pun dapat dikatakan belum membuang sampah dengan benar. Mereka masih sering membuang sampah dengan mencampur antara sampah organik dengan anorganik. Padahal kita tahu sampah-sampah tersebut jika dipisahkan dapat di daur ulang kembali dan dapat menciptakan manfaat ekonomis. Dalam 30 tahun terakhir, isu lingkungan meningkat dan menjadi keperihatinan baik dari segi politik dan sosial, hal ini mulai menarik bagi para peneliti di bidang pemasaran dan ilmu sosial (e.g., Shrum et al., 1994a). Kebanyakan dari penelitian daur ulang memandang masalah ini sebagai salah satu perubahan keperilakuan. Konsekuensinya adalah secara tidak mengejutkan terdapat banyak penelitian mengenai daur ulang sampah yang diteliti dari perspektif psikologi. McCarthy dan Shrum (2001) berpendapat bahwa memahami dan memprediksi perilaku ramah lingkungan terbukti sungguh menyulitkan. Salah satu permasalahan yang muncul baik dari segi akademik maupun terbitan populer adalah bahkan ketika terlihat bahwa semua orang memiliki sikap dan keyakinan yang positif terkait dengan lingkungan, perilaku pro-lingkungan (pembelian dan pembuangan sampah) tersebut tidak selalu sama di berbagai tempat.

Model yang dijadikan rujukan utama dalam penelitian ini adalah model yang dari McCarty dan Shrum (2001). Mereka menemukan bahwa ada tiga nilai dasar yang berhubungan dengan interaksi seseorang pada lingkungan dan orang lain yang akan mempengaruhi perilaku mendaur ulang. Dua dari konstruk itu adalah individualisme dan kolektivisme yang berhubungan dengan interaksi manusia dengan manusia lain. Konstruk 
ketiga adalah locus of control, yaitu keyakinan dasar tentang hubungan manusia dan interaksinya dengan lingkungan mereka.

Beberapa hasil penelitian mengungkapkan bahwa adanya insentif moneter ataupun penghargaan mampu mendorong seseorang untuk melakukan sebuah perilaku ataupun meningkatkan intensitas perilaku seseorang (misalnya lihat Allen et al., 1993; Garces et al., 2002; Lehman dan Geller, 2004; Bezzina dan Dimech, 2011). Pelton et al. (1993) menyatakan bahwa insentif dianggap mampu memperkuat niat seseorang dan meningkatkan intensitas perilaku seseorang sesuai dengan Stimulus-Response Theory. Teori ini menyatakan bahwa niat seseorang untuk melakukan sebuah perilaku bisa dipengaruhi oleh satu atau lebih stimuli, yang mana stimuli ini mungkin menjadi pengaruh yang signifikan bagi terbentuknya sebuah perilaku (Pelton et al. 1993). Thøgersen (1994) dan Santopietro (1995) turut menegaskan bahwa para ekonom neoklasik merekomendasikan penggunaan insentif moneter guna mendorong seseorang untuk melakukan sebuah perilaku. Garces et al. (2002) menyatakan bahwa sebagai rangsangan yang mampu mengkondisikan sikap terhadap sebuah program daur ulang yang ditetapkan.

Indonesia di setiap tahunnya terus mengalami peningkatan jumlah penduduk turut mengalami masalah sampah yang serius. Kota Salatiga pada tahun 2003 menghasilkan sampah sejumlah 363,98 m3/hari dan pada tahun 2004 meningkat menjadi $389 \mathrm{~m} 3 /$ hari. Rendahnya kesadaran masyarakat di Kota Salatiga dalam hal pengelolaan sampah turut menimbulkan dampak negatif, seperti terjadinya krisis air bersih yang diakibatkan tercemarnya mata air oleh berbagai jenis limbah padat

\section{Rumuasan Masalah}

Berdasarkan latar belakang di atas, permasalahan praktis yang muncul adalah belum munculnya perilaku mendaur ulang sampah oleh masyarakat kota Salatiga. Perilaku masyarakat saat ini kebanyakan langsung membuang sampah rumah tangga. permasalahan teroritis yang ada adalah (1) apakah variabel locus of control internal berpengaruh terhadap perilaku mendaur ulang dan (2) apakah insentif berpengaruh terhadap perilaku mendaur ulang 


\section{PAPARAN TEORITIS DAN HIPOTESIS}

1. Perilaku Mendaur Ulang

Mendaur ulang sampah rumah tangga merupakan hal yang penting dalam manajemen pengelolaan sampah padat namun terkadang dianggap sebagai hal yang kotor dan membuang waktu yang mengakibatkan masyarakat menghindarinya (Ebreo et al., 1999). Mendaur ulang sampah membutuhkan sedikit dari usaha seorang individu untuk memilih sampah rumah tangga dan membawanya ke fasilitas daur ulang. Mendaur ulang juga termasuk menggunakan kembali dan memperbaiki material, seperti pakaian dan perabot rumah daripada membuangnya (Nordlund dan Garvill, 2002).

Beberapa tinjauan literatur dalam penelitian daur ulang menghasilkan sejumlah besar penelitian yang berkaitan dengan berbagai banyak aspek mengenai daur ulang (Shrum et al., 1994b). Variasi penelitian berkisar dari karakteristik dari pendaur ulang sampai strategi intervensi yang bertujuan untuk meningkatkan perilaku mendaur ulang secara lebih spesifik. Shrum et al. (1994b) berpendapat bahwa bahwa kebanyakan penelitian menganggap bahwa permasalahan daur ulang merupakan salah satu dari perubahan keperilakuan. Akibatnya, tidak mengherankan lagi bahwa bagian terbesar dari penelitan daur ulang dikembangkan dari perspektif psikologi.

Mendaur ulang sampah rumah tangga merupakan hal yang penting dalam manajemen pengelolaan sampah padat namun terkadang dianggap sebagai hal yang kotor dan membuang waktu yang mengakibatkan masyarakat menghindarinya (Ebreo et al., 1999). Mendaur ulang sampah membutuhkan sedikit dari usaha seorang individu untuk memilih sampah rumah tangga dan membawanya ke fasilitas daur ulang. Mendaur ulang juga termasuk menggunakan kembali dan memperbaiki material, seperti pakaian dan perabot rumah daripada membuangnya (Nordlund dan Garvill, 2002).

Masyarakat memiliki karakter dan perilaku yang buruk tentang sampah. Masyarakat Indonesia masih belum memiliki kesadaran arti pentingnya membuang sampah apalagi mendaur ulang sampah rumah tangga yang mereka hasilkan. Mereka seringkali membuang sampah di sembarang tempat. Jika kesadaran membuang sampah secara benar belum tercapai, maka perilaku masyarakat untuk mendaur ulang sampah pun masih jauh 
dari harapan. Walaupun mereka mempunyai tingkat pendidikan dan status ekonomi yang tinggi, perilaku membuang sampah sembarangan-pun masih terlihat.

Dari kegiatan-kegiatan pelatihan, penyuluhan, atau seminar-seminar tentang pengelolaan sampah secara bertahap diharapkan terjadi perubahan perilaku masyarakat. Masyarakat tidak lagi membuang sampah sembarangan di selokan atau saluran air dengan membuangnya sampah pada tempatnya. Masyarakat mulai memisahkan sampah sesuai kelompoknya: organik, plastik, logam, dan kaca dan tidak membakarnya. Masyarakat yang telah melakukan hal di atas berarti mereka telah mempunyai perilaku membuang sampah secara benar.

\section{Locus of Control Internal}

Pengembangan pengukuran di bidang yang lebih spesifik dari Locus of control (LOC) bukanlah merupakan hal yang baru bagi peneliti. Penelitian sebelumnya telah menggunakan LOC untuk mengukur perilaku konsumen (Busseri et al., 1998), jasa (Bradley dan Sparks, 2002), penjualan (Chung, 2001), dan bidang-bidang lainnya. Locus of control mengacu pada sejauh mana seseorang mempercayai bahwa mereka memiliki kemampuan untuk mempengaruhi sebuah hasil melalui aksi mereka sendiri (Rotter, 1966). Konsep ini berdasarkan kepercayaan bahwa beberapa individu tidak berusaha membawa perubahan karena mereka menghubungkan perubahan pada kesempatan atau pada seseorang yang lebih kuat (Tuhan, orang tua, dan pemerintah) daripada pada perilaku mereka sendiri. Cleveland et al. (2005) menyatakan bahwa keputusan konsumen untuk menentukan apakah mereka dapat mempengaruhi perubahan atau tidak adalah berdasarkan tingkat pengendalian akan tindakan dan perilaku pro-lingkungan mereka.

Beberapa penelitian telah memperlihatkan bahwa locus of control diasosiasikan dengan isu-isu lingkungan hidup. Balderjahn (1988) menemukan bahwa kontrol ideologis besar yang diterima secara positif berhubungan dengan sikap terkait dengan kesadaran lingkungan dan pembelian produk ramah lingkungan. Schwepker dan Cornwell (1991) melaporkan bahwa bukti menunjukkan sebuah locus of control internal berhubungan dengan kecenderungan untuk membeli produk yang berkemasan ramah lingkungan. Hines et al. (1987 dalam Cleveland, 2005) menyimpulkan bahwa adanya locus of control internal berhubungan positif dengan perilaku tanggung jawab ramah lingkungan. Locus of 
control internal mungkin memberikan seseorang sebuah keyakinan bahwa mereka dapat berbuat sesuatu untuk merubah lingkungan. Oleh sebab itu, internal seharusnya lebih cenderung mempercayai bahwa tindakan mereka yang terkait dengan lingkungan memang bermanfaat. Seseorang yang lebih internal akan cenderung mempercayai bahwa membuang sampah secara benar merupakan hal yang penting daripada mereka yang kurang internal (lebih eksternal).

\section{H1: Locus of control internal berpengaruh positif pada keyakinan tentang pentingnya mendaur ulang sampah.}

\section{Insentif}

Di berbagai negara, skema insentif ekonomi saat ini yang saat ini diluncurkan bertujuan untuk meningkatkan daur ulang sampah rumah tangga secara umum (Pearce dan Turner, 1992). Ekonomis lingkungan mengklaim bahwa sebuah pendekatan berbasis pasar, yang bertujuan untuk memodifikasi perilaku manusia melalui mekanisme harga akan lebih efektif dan efisien. Dasar rasional insentif ekonomi adalah merubah biaya relatif dan keuntungan dari perilaku lingkungan yang bermanfaat (Pearce dan Turner, 1992) dalam rangka membuat hal tersebut menguntungkan bagi individual untuk bertingkah laku sesuai dengan kepentingan bersama. The Utility Maximizing Theory (Pelton et al., 1993) mengungkapkan bahwa sikap seseorang terhadap setiap kegiatan pembuangan dipengaruhi oleh adanya penghargaan atau hukuman yang melekat pada kegiatan tersebut. Hal ini sesuai dengan Wasserstorm (1979, dalam Pelton et al., 1993) yang menyatakan bahwa keputusan seseorang untuk berpartisipasi dalam kegiatan daur ulang bisa dikarenakan adanya dorongan/perintah moral, yang mana hal tersebut bisa dianggap sebagai sebuah penyederhanaan ataupun penyelesaian bagi konflik kepentingan yang terjadi dan mampu mengoptimalkan kondisi yang saling menguntungkan bagi orang-orang yang tinggal dalam satu kelompok (Rest, 1986 dalam Pelton et a.l, 1993). Oleh karena itulah, selain dilakukan atas dasar moral, perilaku ekologi juga dilakukan atas dasar keinginan atau harapan untuk meningkatkan keuntungan, baik bagi individu maupun bagi orang banyak. Pernyataan ini sesuai dengan Stimulus-Response Theory yang 
mengungkapkan bahwa niat seseorang untuk melakukan sebuah perilaku bisa dipengaruhi oleh satu atau lebih stimuli (Pelton et al., 1993).

De Young (1993) dan Geller et al. (1982) menyatakan bahwa insentif dapat mendorong adanya perilaku yang pro lingkungan hidup. Motivasi masyarakat dalam melakukan daur ulang akan lebih besar ketika mereka mendapatkan insentif dari apa yang dilakukannya. Ketika terdapat tempat untuk pengelolaan sampah untuk didaur ulang yang disediakan secara gratis maka masyarakat akan terdorong untuk melakukan daur ulang apalagi ditambah dengan adanya insentif bagi mereka berupa uang tambahan. Berdasarkan hal tersebut diatas maka dapat dirumuskan hipotesis sebagai berikut:

\section{H2: Insentif berpengaruh positif pada perilaku daur ulang}

\section{DATA DAN SAMPEL PENELITIAN}

Desain untuk penelitian ini adalah survei dengan metode pengumpulan data yang digunakan yaitu self-administered survey. Pada penelitian ini, sebagian besar kuesioner diisi secara mandiri oleh responden dan terdapat beberapa kuesioner yang diisikan oleh peneliti (langsung dilokasi penelitian) sesuai dengan tanggapan responden. Tingkat analisis yang digunakan dalam penelitian ini adalah rumah tangga sehingga unit sampel dalam penelitian ini adalah rumah tangga di Kota Salatiga. Unit sampel yang dipilih adalah individu dalam rumah tangga karena penelitian ini lebih ingin melihat pada perilaku mendaur ulang dari sampah yang dihasilkan oleh rumah tangga. Metode penyampelan yang digunakan adalah nonprobability sampling, sedangkan teknik sampling yang digunakan adalah judgement sampling. Secara keseluruhan, jumlah kuesioner yang disebarkan sebanyak 100 buku kecil dan dari jumlah tersebut total kuesioner yang kembali sebanyak 90, sehingga secara keseluruhan tingkat respon yang didapat sebesar $90 \%$.

Setiap konstruk diukur dengan berapa item pertanyaan yang kebanyakan diadaptasi dari penelitian sebelumnya. Konstruk locus of control internal diukur dengan menggunakan item pertanyaan dari McCarty dan Shrum (2001). Konstruk perilaku mendaur ulang dan insentif mengadopsi item pertanyaan dari Bezzina dan Dimmech 
(2010). Semua item pertanyaan menggunakan skala diferensial semantic 7 poin yaitu dari sangat tidak setuju sampai sangat setuju.

\section{METODE ANALISIS DATA}

1. Uji Validitas

Uji validitas dilakukan guna mengetahui apakah sekumpulan butir-butir pertanyaan/pernyataan mampu mengukur secara akurat konsep atau konstruk yang ingin diukur, bukan konsep atau konstruk lain (Sekaran, 2003:206). Construct validity adalah tipe pengukuran validitas yang menggunakan multipel indikator dan memiliki sub tipe. Construct validity menunjukkan bahwa nilai-nilai yang diperoleh dari butir-butir pernyataan dalam instrumen yang mengukur konsep yang sama akan memiliki korelasi yang tinggi (Sekaran, 2003:207). Metode yang digunakan adalah Confirmatory Factor Analysis (CFA) dengan bantuan program SPSS for Windows.

\section{Uji Reliabilitas}

Reliabilitas instrumen terdiri dari beberapa tipe yaitu reliabilitas stabilitas, representatif dan kesamaan/ konsistensi internal (Neuman, 2006: 189; Cooper dan Schindler, 2008:294). Reliabilitas instrumen yang akan diuji dalam penelitian ini adalah tipe reliabilitas kesamaan (equivalence) atau konsistensi internal. Jenis reliabilitas ini digunakan karena penelitian ini menggunakan banyak indikator. Reliabilitas kesamaan dianggap baik jika beberapa indikator berbeda mengukur konstruk yang sama memberikan hasil pengukuran yang konsisten atau sama dengan pengukuran yang konsisten atau sama dengan hasil pengukuran semua indikator dari konstruk yang sama (Neuman, 2006:190). Reliabilitas diuji dengan menggunakan Cronbach's alpha (Neuman, 2006:190) dengan koefisien Cronbanch's alpha minimal 0,70 meskipun nilai 0,6 masih dapat diterima (Hair et al., 2010: 778). Pengukuran reliabilitas masing-masing konstruk dilakukan secara terpisah.

\section{Uji Hipotesis}

Analisa data dilakukan dengan menggunakan metode analisa kuantitatif yaitu dengan mengumpulkan, mengolah, dan menginterpretasikan data yang diperoleh sehingga memberi keterangan yang benar dan lengkap untuk pemecahan masalah yang dihadapi. Metode analisis data yang digunakan dalam penelitian ini adalah model regresi sederhana 
dengan menggunakan bantuan software SPSS for window 12.5. Jenis pengujian yang dapat dipakai dalam penelitian ini, yaitu uji asumsi klasik dan pengujian hipotesis.

Regresi linear merupakan suatu metode analisis statistik yang mempelajari pola hubungan antara dua atau lebih variabel. Pada kenyataan sehari-hari sering dijumpai sebuah kejadian dipengaruhi oleh lebih dari satu variabel. Analisis regresi linier berganda memberikan kemudahan bagi pengguna untuk memasukkan lebih dari satu variabel prediktor hingga $\mathrm{p}$-variabel prediktor dimana banyaknya $\mathrm{p}$ kurang dari jumlah observasi (n). Regresi linier berganda, digunakan untuk mengetahui independen variabel mana saja (locus of control internal dan intensif), yang merupakan prediktor variabel dependen (Perilaku mendaur ulang).

$$
Y=\alpha+\beta_{1} X_{1}+\beta_{2} X_{2}+\varepsilon
$$

Keterangan:

Y: Perilaku Mendaur Ulang

$\alpha$ : Konstanta

$\beta_{1}$ : Koefisien regresi

$\mathrm{X}_{1}$ : locus of control internal

$\mathrm{X}_{2}$ : intensif

\section{ANALISIS DATA DAN PEMBAHASAN}

1. Uji Validitas

Pengujian validitas konvergen berdasarkan nilai factor loadings dilakukan dengan menggunakan analisis faktor konfirmatori (CFA) dengan menggunakan batas minimal nilai factor loadings untuk setiap butir atau indikator adalah 0,5, meskipun idealnya adalah 0,7 atau lebih tinggi (Hair dkk., 2010:709). Dari hasil Kaiser-Meyer-Olkin Measure of Sampling Adequency (KMO MSA) seperti yang terlihat pada Tabel 1, didapatkan hasil 0.831. Hasil ini menunjukkan bahwa dapat dilakukan analisis faktor karena syarat yang harus dipenuhi untuk melakukannya adalah KMO > 0.05. 
Tabel 1

KMO and Bartlett's Test

\begin{tabular}{|ll|r|}
\hline Kaiser-Meyer-Olkin Measure of Sampling Adequacy. & .831 \\
Bartlett's Test of Sphericity & Approx. Chi-Square & $2.125 \mathrm{E} 3$ \\
& $\mathrm{df}$ & 78 \\
& Sig. & .000 \\
\hline
\end{tabular}

Tabel 2

Hasil Uji Validitas Konvergen

\begin{tabular}{|l|l|l|l|}
\hline & Perilaku Daur Ulang & Insentif & Locus of Control \\
\hline LOC1 & & & 0,754 \\
\hline LOC2 & & & 0,719 \\
\hline LOC3 & & & 0,805 \\
\hline INS2 & & 0,571 & \\
\hline INS3 & & 0,699 & \\
\hline INS4 & & 0,805 & \\
\hline INS5 & & 0,866 & \\
\hline PDU1 & 0,849 & & \\
\hline PDU2 & 0,851 & & \\
\hline PDU3 & 0,814 & & \\
\hline PDU4 & 0,788 & & \\
\hline
\end{tabular}

Hasil dari analisis faktor menunjukkan bahwa semua indikator untuk konstruk LOC, dan PDU memiliki nilai factor loadings diatas 0,5 dan telah mengelompok sesuai dengan konstruknya masing-masing. Untuk konstruk LOC, terdapat salah satu indikator yaitu LOC4 yang tidak mengeluarkan nilai, maka diputuskan untuk membuangnya dan setelah membuangnya hasil yang diperoleh adalah variabel LOC sudah mengumpul pada komponennya. Peneliti memutuskan untuk membuang indikator LOC4 karena masyarakat saat ini sudah terlalu banyak memikirkan hal lain selain permasalahan sampah. 
Permasalahan sampah sendiri mereka anggap sebagai masalah yang harus diselesaikan oleh pihak pemerintah bukan oleh masyarakat. Indikator untuk konstruk INS tidak mengelompok dalam satu dimensi, melainkan membentuk dua dimensi. Indikator INS1 dan INS2 mengelompok pada dimensi dua dan indikator INS3 hingga INS5 mengelompok pada dimensi satu. Namun, ketika peneliti menghilangkan salah satu dari dua indikator yang mengelompok pada dimensi dua tersebut (INS1 atau INS2), keempat butir indikator INS tersebut sudah mampu mengelompok pada satu dimensi. Peneliti memutuskan untuk menghilangkan butir indikator INS2 dan mempertahankan indikator INS1. Dipertahankannya indikator INS1 dan dihilangkannya indikator INS2 tersebut dikarenakan butir pernyataan dari INS2 lebih mencerminkan konstruk insentif dibandingkan dengan butir pernyataan dari INS1. Butir pernyataan dari INS2 yang menyatakan tentang ketersediaan wadah sampah secara mudah dianggap lebih dapat menggambarkan konstruk insentif yang pengaruhnya dapat secara langsung dirasakan oleh responden dibandingkan butir pernyataan dari INS2 yang menyatakan tentang ketersediaan wadah sampah secara murah. Selanjutnya, hasil analisis faktor dengan menghilangkan indikator INS1 memberikan nilai factor loadings diatas 0,5 untuk keempat indikator INS lainnya (INS2, INS3, INS4, dan INS5) dan semua butir indikator tersebut pada akhirnya mampu mengelompok pada satu dimensi INS.

\section{Uji Reliabilitas}

Pengukuran reliabilitas masing-masing konstruk dilakukan secara terpisah. Hasil perhitungan koefisien Cronbach's alpha dengan menggunakan SPSS 16.0 for Windows setelah mengeluarkan butir INS2 memberikan nilai Cronbach's alpha diatas 0,7 untuk semua konstruk. Hasil ini menunjukkan bahwa semua butir atau indikator dari masingmasing konstruk telah reliabel. Nilai Cronbach's alpha untuk masing-masing konstruk dapat dilihat pada Tabel 3 
Tabel 3

Hasil Pengujian Reliabilitas

\begin{tabular}{|l|l|l|}
\hline \multicolumn{1}{|c|}{ Variable } & \multicolumn{1}{c|}{$\begin{array}{c}\text { Corrected Item - } \\
\text { Total Correlation }\end{array}$} & Cronbach's Alpha \\
\hline Locus Of Control Internal & & 0,752 \\
\hline LOC1 & 0,575 & \\
\hline LOC2 & 0,578 & \\
\hline LOC3 & 0,644 & 0,888 \\
\hline Perilaku Mendaur Ulang & & \\
\hline PDU1 & 0,777 & \\
\hline PDU2 & 0,796 & \\
\hline PDU3 & 0,739 & \\
\hline PDU4 & 0,706 & \\
\hline Insentif & & \\
\hline INS2 & 0,359 & \\
\hline INS3 & 0,453 & \\
\hline INS4 & 0,585 & \\
\hline INS5 & 0,657 & \\
\hline
\end{tabular}

\section{Uji Hipotesis}

Pada bagian ini model regresi berganda diterapkan untuk menguji variabel independen yaitu kolektivisme, Perceived Consumer Effectiveness, dan kepedulian lingkungan pada variabel dependen yaitu perilaku pembelian ramah lingkungan. Pada model regresi berganda ini digunakan SPSS for Windows dan pada regresi menggunakan metode enter. Metode enter adalah metode yang memasukkan semua variabel independen kedalam persamaan regresi. Maka dapat ditulis model regresi sebagai berikut

Tabel 4

Persamaan Regresi Berganda

\begin{tabular}{cccc}
\hline Variabel & $\beta$ & $\mathrm{t}_{\text {hitung }}$ & \multicolumn{2}{l}{ Sig } \\
\hline Konstan & $-0,515$ & & \\
$\mathrm{X} 1$ & 0,230 & 3,444 & 0,001 \\
$\mathrm{X} 2$ & 0,739 & 13,593 & 0,000 \\
\hline $\mathrm{R}^{2}=$ & 0,398 & & \\
\hline
\end{tabular}


Untuk menentukan besarnya kontribusi suatu variabel independen (X) terhadap variabel dependen (Y) dapat digunakan koefisien determinasi. Koefisien determinasi secara simultan dapat dilihat dalam tabel model summary sebagai berikut:

\section{Tabel 5}

\section{Koefisien Determinasi}

\begin{tabular}{|l|r|r|r|r|}
\hline \multicolumn{1}{|c|}{ Model Summary } \\
\hline Model & \multicolumn{1}{|c|}{ R } & R Square & $\begin{array}{c}\text { Adjusted R } \\
\text { Square }\end{array}$ & $\begin{array}{r}\text { Std. Error of } \\
\text { the Estimate }\end{array}$ \\
\hline 1 & $.631^{\mathrm{a}}$ & .398 & .394 & 1.15243 \\
\hline
\end{tabular}

a. Predictors: (Constant), INS, LOC

Dari tabel 5 diatas dapat disimpulkan bahwa nilai koefisien determinasi $\left(\mathrm{R}^{2}\right)$ secara simultan adalah sebesar 0,398, hal ini berarti 39,80\% variabel Perilaku Daur ulang dipengaruhi oleh variasi dari kedua variabel independen Locus of Control Internal dan Insentif . Sedangkan sisanya sebesar 60,20\% dipengaruhi oleh variabel lain yang tidak diteliti dalam penelitian ini. Dan dari nilai adjusted $R$ square hasilnya adalah 0,394 ini artinya bahwa hasil regresi variabel Locus of Control Internal dan Insentif dapat menerangkan Perilaku daur ulang sebesar 39,4\%.

Tabel 6

Uji Statistik F

\begin{tabular}{|c|c|c|c|c|c|c|}
\hline \multicolumn{7}{|c|}{ ANOVA $^{b}$} \\
\hline \multicolumn{2}{|c|}{ Model } & $\begin{array}{l}\text { Sum of } \\
\text { Squares }\end{array}$ & df & Mean Square & $\mathrm{F}$ & Sig. \\
\hline 1 & Regression & 285.226 & 2 & 142.613 & 107.381 & $.000^{\mathrm{a}}$ \\
\hline & Residual & 431.634 & 325 & 1.328 & & \\
\hline & Total & 716.860 & 327 & & & \\
\hline
\end{tabular}

a. Predictors: (Constant), INS, LOC

b. Dependent Variable: PDU 
Dari uji ANOVA atau $\mathrm{F}$ test didapat nilai $\mathrm{F}$ Hitung sebesar 107, 381 dengan probabilitas 0,000. Karena probabilitas jauh lebih kecil dari 0,05, maka model regresi dapat digunakan untuk memprediksi Perilaku Daur Ulang atau dapat dikatakan bahwa Locus of Control Internal dan Insentif secara bersama-sama berpengaruh terhadap Perilaku Daur Ulang.

Pengujian hipotesis secara simultan dapat dilihat dari tabel Uji Statistik t . Dengan menggunakan perhitungan SPSS dalam uji hipotesis adalah sebagai berikut:

- H0 ditolak atau pengaruh signifikan apabila:

Significance F Change $<\alpha=0,05$

- H0 diterima atau pengaruh tidak signifikan apabila:

Significance F Change $>\alpha=0,0$

Tabel 7

Uji Statistik t

Coefficients $^{\mathbf{a}}$

\begin{tabular}{|rr|r|r|r|r|r|}
\hline \multirow{2}{*}{ Model } & \multicolumn{3}{|c|}{$\begin{array}{c}\text { Unstandardized } \\
\text { Coefficients }\end{array}$} & $\begin{array}{c}\text { Standardized } \\
\text { Coefficients }\end{array}$ & \multicolumn{1}{c|}{} \\
\cline { 2 - 5 } & \multicolumn{1}{|c|}{$\mathrm{B}$} & Std. Error & \multicolumn{1}{c|}{ Beta } & \multicolumn{1}{c|}{$\mathrm{t}$} & \multicolumn{1}{c|}{ Sig. } \\
\hline 1 & (Constant) & -.515 & .413 & & -1.246 & .214 \\
& LOC & .230 & .067 & .150 & 3.444 & .001 \\
& INS & .739 & .054 & .591 & 13.593 & .000 \\
\hline
\end{tabular}

a. Dependent Variable: PDU

\section{a) Locus of Control Internal terhadap Perilaku Pembelian Daur Ulang}

Prosedur pengujian hipotesis dilakukan dengan cara sebagai berikut:

1. Hipotesis

Ho: Locus of Control Internal berpengaruh negatif pada Perilaku Daur Ulang

Ha: Locus of Control Internal berpengaruh positif pada Perilaku Daur Ulang 
2. Hipotesis secara statistik

Ho: $\beta_{i}=0$

Ha: $\beta_{i} \neq 0$

3. Kriteria Uji

Tolak Ho jika nilai signifikansi lebih kecil dari $\alpha=5 \%$.

4. Keputusan

Karena hasil pada tabel 7 menunjukkan nilai signifikansi sebesar 0.001 (lebih kecil dari $\alpha=5 \%$ ), maka Ho ditolak. Hal ini menunjukkan bahwa Locus of Control Internal (X1) berpengaruh secara signifikan terhadap Perilaku Pembelian Ramah Lingkungan.

\section{b) Insentif terhadap Perilaku Daur Ulang}

Prosedur pengujian hipotesis dilakukan dengan cara sebagai berikut:

1. Hipotesis

Ho: Insentif berpengaruh negatif pada Perilaku Daur Ulang.

Ha: Insentif berpengaruh positif pada Perilaku Daur Ulang

2. Hipotesis secara statistik

Ho: $\beta_{i}=0$

Ha: $\beta_{\mathrm{i}} \neq 0$

3. Kriteria Uji

Tolak Ho jika nilai signifikansi lebih kecil dari $\alpha=5 \%$.

4. Keputusan

Karena hasil pada tabel 7 menunjukkan nilai signifikansi sebesar 0.000 (lebih kecil dari $\alpha=5 \%$ ), maka Ho ditolak. Hal ini menunjukkan bahwa Insentif (X2) berpengaruh secara signifikan terhadap Perilaku Daur Ulang.

\section{PEMBAHASAN}

Meskipun konteks dan objek penelitiannya berbeda temuan ini sesuai dengan hasil empiris penelitian-penelitian terdahulu seperti penelitian yang telah dilakukan oleh McCarty dan Shrum (2001), Barderjahn (1988), Schwepker dan Cornwell (1991), dan Hines, Hungerford, dan Tomera (1987). Temuan ini menjelaskan bahwa responden yang 
memiliki locus of control internal akan percaya bahwa mendaur ulang adalah merupakan kegiatan atau sesuatu yang penting untuk dia lakukan melalui aksi mereka. Dengan demikian, locus of control internal menjadi sumber munculnya tentang keyakinan pentingnya mendaur ulang sampah. Semakin konsumen memiliki tingkat locus of control internal maka ia semakin yakin tentang pentingnya mendaur ulang sampah rumah tangga yang ia hasilkan.

Karena arah hubungannya positif maka semakin meningkat locus of control internal akan meningkatkan pula keyakinan tentang pentingnya mendaur ulang begitu pula sebaliknya jika locus of control internal menurun maka keyakinan tentang pentingnya mendaur ulang pun diprediksi akan menurun. Locus of control internal adalah seseorang yang percaya bahwa dia memiliki pengaruh yang substansial dalam kehidupannya dan tindakan mereka akan berpengaruh pada sebuah hasil tertentu (McCarty dan Shrum, 2001). Konsumen yang dari awal percaya bahwa dia memiliki pengaruh untuk membuat perubahan di lingkungan sekitarnya terutama yang berkaitan dengan terciptanya lingkungan yang baik maka ia akan yakin bahwa daur ulang itu penting untuk menciptakan lingkungan yang mereka kehendaki.

Seperti yang kita ketahui banyak jajak pendapat yang menunjukkan bahwa kebanyakan orang memiliki sikap yang positif terhadap lingkungan. Seseorang yang memiliki locus of control internal akan percaya bahwa dia dapat berbuat sesuatu untuk merubah lingkungan di sekitarnya menjadi lebih baik melalui aksi mereka dan di dalam konteks penelitian ini adalah dengan melakukan daur ulang. Oleh karena itu orang akan percaya bahwa tindakan mereka untuk mendaur ulang demi kebaikan lingkungan adalah merupakan hal yang berarti.

Hasil statistik deskriptif memperlihatkan bahwa respon locus of control internal dan keyakinan tentang pentingnya daur ulang rata-rata responden adalah 5.6 dan 6,1. Hal ini menunjukkan bahwa sebagian rata-rata dari responden dalam penelitian ini cenderung memiliki locus of control internal yang tinggi dan yakin pada pentingnya mendaur ulang. Rendahnya pengaruh locus of control internal pada keyakinan tentang pentingnya daur ulang yang hanya sebesar 0,386 memperlihatkan bahwa hanya responden yang merasa dirinya mampu membuat perubahan terkait dengan daur ulang akan merasa yang yakin 
bahwa kegiatan mendaur ulang itu penting seperti yang mereka yakini. Wiener dan Sukhidal (1990) dalam Laroche et al., (2001) menyatakan bahwa salah satu alasan utama yang menghambat seseorang untuk terlibat dalam kegiatan ekologis yang menguntungkan adalah level penerimaan mereka akan keterlibatan dirinya terhadap perlindungan lingkungan hidup. Banyak orang yang memiliki kepedulian ekologis tinggi, tetapi merasakan bahwa pemeliharaan lingkungan merupakan tanggung jawab pemerintah atau perusahaan besar.

Temuan adanya pengaruh insentif terhadap perilaku daur ulang konsisten dengan temuan studi empiris terdahulu yang telah dilakukan oleh Thorgersen (1994), Lee et al. (1995) Geller et al. (1982), dan De Young (1993). Temuan ini menjelaskan bahwa dengan adanya insentif akan meningkatkan perilaku mendaur ulang masyarakat. Karena arah hubungannya positif maka tinggi rendahnya insentif akan berpengaruh searah pada tinggi rendahnya perilaku daur ulang atau dengan kata lain semakin besar insentif yang diterima oleh masyarakat maka dapat diprediksi akan semakin tinggi pula perilaku daur ulang, begitu juga sebaliknya. Selain itu, temuan ini juga sesuai dengan beberapa teori terkait dengan motivasi yaitu Stimulus-Response Theory.

Schultz dan Oskamp (1996) berpendapat bahwa insentif akan meningkatkan jumlah usaha seseorang dalam kesediaanya untuk berperilaku tertentu dan peningkatan ini akan lebih jelas terlihat pada seseorang yang memiliki sikap positif terhadap lingkungan yang rendah. Oleh karena itu dapat diperkirakan bahwa perilaku seseorang dalam mendaur ulang akan meningkat jika mereka menerima insentif ketika melakukan perilaku tersebut. Terkait dengan perilaku pengelolaan sampah, Allen et al., (1993) menambahkan bahwa sikap seseorang terhadap perilaku pembuangan sampah terkait dengan penghargaan dan atau hukuman yang melekat pada perilaku tersebut, dan sikap yang terbentuk akan menentukan apakah dirinya akan melakukan atau tidak melakukan perilaku tersebut. Adanya penghargaan mampu membentuk sikap yang positif terhadap sebuah perilaku dan pada akhirnya mampu mendorong seseorang untuk melakukan perilaku tersebut, sedangkan adanya hukuman akan memaksa seseorang untuk memiliki sikap yang positif terhadap sebuah perilaku dan mendorongnya untuk melakukan perilaku 
tersebut guna menghindari hukuman yang akan dibebankan kepada dirinya jika ia tidak melakukan perilaku tersebut.

Salah satu teori yang mendukung adanya motivasi untuk mendukung suatu perilaku adalah Stimulus-Response Theory. Stimulus-Response Theory merupakan salah satu perspektif dari The Utility Maximization Criteria, yaitu penggambaran yang lebih spesifik dalam mengevaluasi sebuah perilaku guna memutuskan apakah seseorang akan melaksanakan atau tidak melaksanakan sebuah perilaku (Pelton et al., 1993). Pengambilan keputusan tersebut didasarkan atas ketersediaan penghargaan ataupun hukuman yang dianggap sebagai bagian dari sebuah rangsangan. Stimulus-Response Theory menyatakan bahwa niat seseorang untuk melakukan sebuah perilaku bisa dipengaruhi oleh satu atau lebih stimuli, yang mana stimuli ini mungkin menjadi pengaruh yang signifikan bagi terbentuknya sebuah perilaku (Allen et al., 1993).

Dari semua hasil pembuktian hipotesis yang ada, pengaruh insentif pada perilaku menghasilkan pengaruh yang paling besar $(\beta=0,599)$. Hal ini berarti perilaku mendaur ulang masyarakat akan muncul atau bertambah besar ketika ada insentif yang akan mereka dapatkan setelah melakukan perilaku daur ulang. Meneses dan Palacio (2006) berpendapat bahwa respon tentang teknik penghargaan dapat dijelaskan dengan konsep keterlibatan yang rendah yaitu seseorang tidak termotivasi untuk berpikir tentang mendaur ulang akan tetapi lebih pada penghargaan yang akan dia terima. Dari hasil ini maka dapat kita simpulkan pengambil kebijakan khususnya pemerintah daerah harus berperan aktif dalam mendorong perilaku daur ulang rumah tangga. Thorgensen (1994) berpendapat bahwa poin penting terkait dengan keputusan pelaksanaan skema insentif ekonomi adalah analisis yang hati-hati tentang bagaimana instrumen regulasi yang akan dibuat nantinya dapat mempengaruhi persepsi masyarakat tentang hal tersebut.

\section{KESIMPULAN DAN SARAN}

Penelitian ini bertujuan untuk meneliti pengaruh orientasi nilai (kolektivisme dan locus of control internal) pada keyakinan tentang pentingnya daur ulang, pengaruh keyakinan tentang pentingnya daur ulang, keyakinan tentang ketidaknyamanan daur ulang, dan insentif terhadap perilaku daur ulang. Structural Equation Modeling dengan bantuan 
AMOS 4.01 digunakan untuk menguji hipotesis-hipotesis yang diajukan. Adapun hasil penelitian ini dapat disimpulkan sebagai berikut:

1. Locus of control internal berpengaruh positif terhadap keyakinan tentang pentingnya mendaur ulang. Seseorang yang memiliki locus of control internal yakin bahwa mereka dapat berbuat sesuatu untuk merubah lingkungannya kearah yang lebih baik dengan cara mendaur ulang sampah rumah tangga yang dihasilkannya. Mereka dapat menyumbangkan energi dan pikirannya agar dapat mengurangi kerusakan lingkungan yang diakibatkan oleh sampah rumah tangga.

2. Insentif berpengaruh positif terhadap perilaku mendaur ulang. Perilaku mendaur ulang masyarakat akan semakin besar jika ada insentif yang mereka terima ketika melakukan kegiatan mendaur ulang. Insentif yang mereka terima baik itu kemudahan dalam mendaur ulang atau insentif moneter dianggap sebagai pendorong dalam berperilaku karena mereka merasa usaha mereka menjaga lingkungan terutama dengan mendaur ulang terasa lebih mudah dan mendapatkan suatu penghargaan.

Dengan adanya keterbatasan saat dilakukanya penelitian, berikut ini adalah saran untuk penelitian selanjutnya:

a) Fokus penelitan harus diperlebar dengan cara menambah variabel anteseden misalnya dengan menggabungkannya dengan Theory of Planned Behavior sehingga tercipta model daur ulang yang lebih komprehensif.

b) Membedakan jenis insentif yang digunakan dalam penelitian mendaur ulang baik itu hanya dengan menggunakan insentif moneter atau hanya menggunakan insentif non moneter sehingga hasilnya akan lebih jelas.

Untuk memberikan kemudahan responden dalam memberikan jawaban, sebaiknya instrumen penelitian tidak didesain dalam semantic differential akan tetapi misalnya menggunakan skala Likert. 


\section{DAFTAR PUSTAKA}

Allen, J.D; D. Davis; dan M. Soskin (1993), "Using Coupons incentives in recycling aluminum: A Market approach to energy conservation policy," Journal of consumer affairs, Vol.27, pp. 300-318.

Balderjahn, I. (1988), "Personality Variables and Environmental Attitudes as Predictors of Ecologically Responsible Consumption Patterns," Journal of Business Research, Vol. 17, pp.51-56.

Bezzina, F.H. dan S. Dimech (2011), "Investigating the Determinants of Recycling Behavior in Malta," Management of Environmental Quality: an International Journal, Vol. 22, No. 4, pp. 463-485.

Bradley, G. L., dan B.A. Spark (2002), "Service Locus of Control: It's Conceptualization and Measurement," Journal of Service Research, Vol. 4, No. 4, pp. 312-324.

Busseri, M.A.; H. Lecourt; dan R.R. Kerton (1998), "Locus of Control for Consumer Outcomes: Predicting Consumer Behavior," Journal of Applied Social Psychology, Vol. 28, No. 12, pp. 1067-87.

Chung, Y.Y. (2001), "The Development and Evaluation of the Sales Work Locus of Control Scale," International Journal of Management, Vol. 18, No. 2, pp. 231-240.

Clevaland, M., M. Kalamas, dan M. Laroche (2005), "Shades of Green: Linking Environmental Locus of Control and Pro-Environmental Behaviors," Journal of Consumer Marketing, Vol.22, No.4, pp. 198-212.

Cooper, D.R dan P.S. Schindler (2008), “Business Research Methods," $10^{\text {th }}$ edition, New York: McGraw-Hill/Irwin.

Ebreo, A.; J. Hershey; dan J. Vining (1999), "Reducing Solid Waste: Linking Recycling to Environmentally Responsible Consumerism," Environment and Behavior, Vol. 31, 107-135.

Garces, C.; A. Lafuente; M. Pedraja; dan P. Rivera, "Urban Waste Recycling Behavior: Antecedent of Participation in a Selective Collection Program," Environmental Management, Vol.30, No. 3, pp. 378-390.

Hair, J.R.; R.E. Anderson; R.L Tantham; dan W.C. Black (2010), “Multivariate Data Analysis, " $7^{\text {th }}$ edition, Upper Saddle River, NJ; Prentice Hall, Inc. 
Kaplan, S. (2000), "Human Nature and Environmentally Responsible Behavior," Journal of Social Issue, Vol. 56 (3), pp. 491-508

Kim, Y. and S.M. Choi (2005), "Antecedents of Green Purchase Behavior: An Examination of Collectivism, Environmental Concern, and PCE," Advance in Consumer Research, Vol 32, pp. 592-599.

Lehman, P.K. dan E.S. Geller (2004), "Behavior Analysis and Environmental Protection: Accomplishments and Potential for More," Behavior and Social Issues, Vol. 14, pp. 13-32.

McCarty, J.A. dan L.J. Shrum (2001), “The Influence of Individualism, Collectivism, and Locus of Control on Environmental Beliefs and Behavior," Journal of Public Policy \& Marketing, Vol. 20, No. 1, pp. 93-104.

Meneses, G.D. dan A.B. Palacio (2006), "Different Kinds of Consumer Response to the Reward Recycling Technique: Similarities at the Desired Routine Level," Asia Pacific Journal of Marketing and logistics, Vol. 18 (1), 43-60.

Neuman, W.L. (2006), "Social Research Methods: Qualitative and Quantitative Approaches," $6^{\text {th }}$ edition, Boston: Pearson.

Nordlund, A.M. dan J. Garvill (2002), "Value Structure behind Proenvironmental Behavior," Environment and Behavior, Vol. 34 (6), 740-756.

Pearce, D. W., dan R. K. Turner (1993), "Market-based Approaches to Solid Waste Management," Resources, Conservation and Recycling, Vol. 8, pp. 63-90.

Pelton, L.E.D; D. Strutton; J. H. Barnes; dan S.L. True (1993), “The Relationship Among Referents, Opportunity, Rewards, and Punishment in Consumer Attitude Toward Recycling: A Structural Equation Approach," Journal of Micromarketing, Vol. 13, pp. 60-74.

Rotter, J.B. (1996), “Generalized expectancies for Internal versus External Control of Reinforcement," Psychological Monographic: General and Applied, Vol. 80, No. 1, pp. 1-28.

Santopietro, G.D. (1995), "Raising Environmental Consciousness versus Creating Economic Incentives as Alternative Policies for Environmental Protection," Journal of Economic Issues, Vol. 29 (2), pp. 517-524.

Schultz, P.W dan S. Oskamp (1996), "Efforts as a mediator of attitude-behavior relationship: General Environmental Concern and recycling," Social psychology quarterly, vol. 59 (4) 375-383. 
Schwepker, C.H. dan T.B Cornwell (1991), "An Examination of Ecologically Concerned Consumer and Their Intention to Purchase Ecologically Packaged Products," Journal of Public Policy and Marketing, 10 (Fall), pp. 77-101.

Sekaran, Uma dan Roger Bougie. (2010), Research Methods For Bussines: Skill Building Approach, $5^{\text {th }}$ ed, John Willey and Sons Ltd.

Shrum, L.J.; J.A. McCarthy; and T.M. Lowrey (1994a), "Buyer Characteristics of The Green Consumer and Their Implication of Advertising Strategy," Journal of Advertising, Vol 24, No 2, pp. 71-82.

Shrum, L.J.; T.M. Lowrey; dan J.A. McCarty (1994b), "Recycling as a Marketing Problem: A Framework for Strategy Development," Psychology and Marketing, Vol. 11, No.4, pp. 393-416.

Thøgersen, John. (1994), "Monetary Incentives and Environmental Concern: Effect of Differentiated Garbage Fee," Journal of Consumer Policy, Vol. 17, No. 4, pp. 407-442. 